\title{
14
}

\section{GERMANY \\ Continuity and change marked by a turbulent history}

\author{
Hans Peter Peters, Markus Lehmkuhl \\ and Birte Fähnrich
}

In Germany, science popularisation through public talks of scientists, public shows, museums, popular science magazines and even newspapers dates back to the 19th century. The post-war development of science communication in West Germany was characterised by the (modified) adoption of two AngloSaxon models: US science journalism leading to professionalisation of science journalism in the 1980s and the British public engagement approach in the second half of the 1990s. In both cases, charitable foundations played a key role. Science journalism in communist East Germany had an ideological mission and was therefore supported by the state but adopted the Western approach after German reunification in 1990. Since the 1960s, universities and other science organisations had already built a capacity for public relations that at first mainly targeted journalistic media but subsequently expanded towards events, face-to-face interactions and citizen science in the context of the new 'engagement' paradigm. Since the late 1990s, several interactive science centres that complemented traditional science museums were established. Science organisations, charitable foundations and the government contributed to the creation of a national science communication agency Wissenschaft im Dialog (WiD) that initiates and coordinates many activities. Scientific-technical controversies beginning in the 1970s provided a challenge for science communication. The current government supports public participation in science policy and citizen science. 


\section{Introduction}

Germany has a rich history, cultureand infrastructure of science communication that dates back to the 19th century. After World War II, science communication re-emerged in the late 1950s, initially in the form of science journalism and media-focused science PR and later by adoption of the British model of public engagement with science. Today, science communication is a vital and diverse field. Although affected by the economic crisis of traditional media, science journalism still plays an important role in Germany. Quality newspapers (print and online) offer science reporting; popular science magazines serve those with a stronger interest in science; public TV and radio programs broadcast science documentaries and magazines. German scientists are as motivated for public communication as those in other major science nations and involved in a variety of science communication activities (e.g. Peters et al., 2009). Organisational communication by universities and other publicly funded research organisations such as the Max Planck Society, Fraunhofer Society and the Helmholtz Association is diversified and professional (for an overview, see Fähnrich et al., 2019). At the national level there are different forms of science communication such as the German Science-Media Center, a science-in-dialogue agency (WiD) and traditional science museums, as well as several interactive science centres. A report prepared for the Commission of the European Union concluded that Germany has a 'consolidated science communication culture' (Mejlgaard et al., 2012), in the same way as the United Kingdom, France, Italy, Spain and other major science countries.

However, it is important to note that while we use the modern term 'science communication' as an inclusive label for all forms of public communication of science in this chapter, these activities were hardly discussed as 'science communication' (or Wissenschaftskommunikation in German) before the mid-1990s. In Germany, the term came into use only when the spectrum of science communication activities broadened with the German adoption of the 'public engagement with science' paradigm. Until then, the terms 'science popularisation', 'science and the media' and 'science journalism' were mostly used. There is still no consensus about the meaning of the term 'science communication'. While we use it as an umbrella term, in line with the definition adopted by the Science Communication Section of the German Communication Association (DGPuK) as well as its international use, some German scholars restrict it to communication activities other than those related to mass mediated science.

While Germany has its own tradition of science popularisation, major transformations in the post-war era were based on the reception and adoption of two Anglo-Saxon models: professional US science journalism in the late 
1970 s and 1980s (along with the academic study of science journalism and its institutionalisation as an academic sub-discipline) in former West Germany; and the British 'Public Engagement with Science and Technology' approach with its focus on dialogic forms of science communication in the second half of the 1990s.

After World War II, Germany was divided into the (communist) East Germany and the (democratic) West Germany for almost 45 years until it was reunited in 1990. During the period of separation, science communication developed in both parts of Germany, but the approaches and functions differed in each part. In this chapter, while briefly describing the East German situation, we focus on the post-war development of science communication in West Germany during the phase of separation because developments after reunification in 1990 connected to the West German tradition.

\section{Roots}

Historically, Germany has been a vital place for the development of modern science and its communication. The origins of modern science lay-as in other European countries - in the foundation of science academies and scientific societies (Ausejo, 1994). Whereas universities date back to medieval times (the oldest German university in Heidelberg was founded in 1386), they took their role as central science organisations only in the 19th century in the context of the Prussian university reforms. Under the then minister Wilhelm von Humboldt, the ideals of a humanitarian academic education, the unity of research and teaching and the freedom of science from political intervention were introduced. Moreover, Humboldt (1964) stressed the necessity of the society-orientation of science. The current international discussion of the universities' 'third mission' of interacting with citizens and society (e.g. Laredo, 2007), also taken up in Germany (Himpsl, 2017), seems very much in line with Humboldt's early concept of the modern university.

Other precursors of German science communication were popular presentations of science in the 19th century, especially in the form of scientific experiments conducted in parlours as well as at folk festivals (Weitze and Heckl, 2016, p. 4). Prominent scholars such as Alexander von Humboldt and Ernst Haeckel gave public lectures on science and wrote books that addressed not only academic scholars but also a science-interested public. Since about 1830, the newspaper Kölnische Zeitung employed journalists specialising in the reporting of science and technology (Krüger and Ruß-Mohl, 1989). The popular science magazine Kosmos was launched in 1903, claiming to follow the tradition of Alexander von Humboldt's Kosmos book series, which were published 1845-58 (Faulstich, 2006). 
In this spirit, science museums were founded to make science and technological developments open to the public (Weber, 1993). For example, the natural history museum in Berlin was opened in 1889. Another outstanding historical example of the late 19th century was Urania in Berlin (Wilke, 2013), the first public astronomical observatory and science centre in Germany.

At the beginning of the 20th century, universities recognised the importance of public communication and started to institutionalise press relations (Koenen and Meißner, 2019). Further, museums of science and technology were founded, among them the Deutsches Museum in Munich (1903) and Hygiene-Museum in Dresden (1912). With the establishment of the Nazi Regime, however, science and its public communication were under full political control and censorship and exploited in the regime's propaganda machinery (Nagel, 2012).

\section{Professionalisation of science journalism}

We locate the origin of 'modern' post-war science communication-mostly science journalism at that time-in the mid-1950s. The space flight programs of Russia and the United States led to extensive coverage in print and broadcast media. In West Germany, the newspaper Frankfurter Allgemeine Zeitung started publishing the first regular science section in 1959. The two public TV channels ARD and ZDF established editorial offices for science reporting and launched science programs in 1964. New popular science magazines such as Bild der Wissenschaft (1964) were founded and, in addition, two very successful TV magazines on nature and environment (Ein Platz für wilde Tiere, ARD) and health (Gesundheitsmagazin Praxis, ZDF) were launched in 1956 and 1964 respectively.

The 1970s were characterised by a sudden rise of interest in science journalism as well as a growing interest in its academic study. The quality and quantity of science journalism, the training of science journalists and the collaboration between science and the media were widely considered deficient in West Germany (e.g. Lohmar, 1972; Fischer, 1976; Hömberg, 1980). Hömberg (1990) titled his book on German science journalism The Delayed [Science] Beat and Grabowski (1982) diagnosed Structural Problems of Science Journalism in News Media. ${ }^{1}$

1 See Kohring (2005) for a detailed description of the German discussion of science popularisation up to 1995 . 
In 1980, the Robert-Bosch Foundation started a large Promotional Program for Science Journalism (Göpfert and Schanne, 1998) that targeted science journalism practice and training in the first place, but also included communication scholars in the discourse. The program awarded about 200 scholarships to journalists, many of whom went to the United States to learn from science journalists there. The program provided the initial funding for the first German Chair for Science Journalism at the Free University of Berlin. Winfried Göpfert, then senior science editor at the public TV channel $\mathrm{SFB}$, took this position to become the first German professor of science journalism. The foundation also funded a series of workshops (1982-92) in which scientists, journalists and communication scholars discussed the status of science journalism in Germany. A number of well-known US scholars were invited to these workshops, illustrating the role of US science journalism and science communication research as a model for Germany (Robert Bosch Stiftung, 1985; Göpfert and Bader, 1998). Referring to the United States, Stephan Ruß-Mohl, the main protagonist of the Robert Bosch program, titled his introduction to one of the workshops 'Science Journalism in the Promised Land' (Ruß-Mohl, 1985). The German orientation towards US science journalism was in line with the general influence of the United States on the reconstruction of the German mass media system after World War II by the United States and Great Britain. Two further initiatives followed in 2002-16, funded by Bertelsmann Foundation, Volkswagen Foundation, Stifterverband ${ }^{2}$ and the pharmaceutical company BASF (Lehmkuhl, 2012).

Since the 1980s, science journalism in Germany has broadened, diversified and professionalised in terms of training, associations and infrastructures (e.g. Göpfert, 2006; Wormer, 2006; Hettwer et al., 2008). While there were occasional academic courses on science journalism before 1988 (Krüger and Flöhl, 1982; Robert Bosch Stiftung, 1983), systematic academic training started with a postgraduate science journalism program at the Free University of Berlin in 1988 (Krüger, 1990). Ten years later, in 1998, the Berlin Chair for Science Journalism organised the 5 th international conference of the Network for the Public Communication of Science and Technology (PCST) in Berlin.

German associations of communicators of science, technology and medicine have existed since the 19th century. Many science journalists were members of the Technisch Literarische Gesellschaft (Technical Literary Association, TELI) established in 1929. In 1986, the German science journalism

2 Stifterverband describes itself as 'a joint initiative started by companies and foundations', focusing on 'consulting, networking and promoting improvements in the fields of education, science and innovation'. Although formally not a foundation, it operates in a similar manner. 
association (WPK) was founded; unlike TELI, its membership is strictly confined to professional science journalists (Pütz, 2006). WPK advocates a clearly 'journalistic' approach as critical observer of science in contrast to the affirmative popularisation of science. It tries to keep science journalism and public relations of science clearly separated (Koch and Stollorz, 2006). Since 2004, WPK has been co-organiser of the annual conferences Wissenswerte [Worth knowing] that are particularly addressed at science journalists. WPK also played an important role in the institutionalisation of the German Science-Media Center in 2015, which, unlike the British model (Fox, 2012), can best be described as a journalistic infrastructure for science reporting rather than as an interface of science with the media (Stollorz and Meurer, 2015).

\section{Post-war science communication in East Germany}

In the German Democratic Republic (GDR) science communication was considered an instrument to promote a scientific world view (Weltanschauung). In 1954, at about the same time when the pre-war Urania was re-established in West Berlin, the Society for the Dissemination of Scientific Knowledge (Gesellschaft zur Verbreitung wissenschaftlicher Kenntnisse and later also named Urania) (Gruhn, 1979) was constituted in East Berlin. In contrast to the Western Urania, which put itself in the tradition of the 19th century version, the Eastern Urania connected to the working-class movement tradition of the Open Educational Institute Urania (Freies Bildungsinstitut Urania). That institute had been founded 1924 in Jena during the Weimar Republic and had published the popular science journal Urania until it was banned 1933 when the Nazis took power in Germany (Schmidt-Lux, 2008).

In 1947 the journal was relaunched in East Germany with the same title but a different mission and aiming at a broader public impact (Gruhn, 1979). From the very beginning the dissemination of scientific knowledge was closely connected to the ideological mission of propagating ideas of the biologist Ernst Haeckel (1834-1919) who promoted monism, a kind of antireligious scientism (Schmidt-Lux, 2008). The general idea was to influence people's worldview through political exploitation of science communication. Taking up scientistic, anti-religious traditions from the Weimar period in Germany, the journal was supposed to support the dominant political doctrine of Marxism-Leninism, which presented itself as a scientific worldview. Scientism became a guiding principle of the state, the socialist party and the education system. It was institutionalised in various organisations, 
of which Urania was the most important. The role of the Society for the Dissemination of Scientific Knowledge (Urania) was 'to engage in the fight for raising the atheistic consciousness' (Schmidt-Lux, 2008, p. 56).

Given the ideological focus on scientism, science communication was considered important in several fields, including the education of journalists. Training and licensing for journalism was strictly regulated and Leipzig University was the only place where journalists were educated academically in East Germany (Schemmert and Siemens, 2013). The importance of science as a field of journalism is obvious from the available specialisations in the 1970s: 'science' was one of only four possible specialisations besides 'politics', 'foreign affairs' and 'economy' (Sager, 1975). In contrast, there was no academic offering for journalists to specialise on science reporting at that time in West Germany.

The propagation of scientism in East Germany seems to have been effective: Eurobarometer surveys conducted after the reunion revealed a higher knowledge level and more positive attitudes towards science and technology of respondents from the former East compared to those from West Germany (Noelle-Neumann and Hansen, 1991; Commission of the European Community, 1993). More specifically, differences in responses to the item 'We depend too much on science and not enough on faith' were obvious even 15 years after the reunion, when 42 per cent of the West German respondents agreed with the item compared to only 31 per cent of East German respondents (European Commission, 2005). A small but consistent East-West difference is still present in the German science barometer 2018 across several questions, indicating a somewhat more positive image of science and technology in the eastern part of the country (Wissenschaft im Dialog, 2018). Other factors besides ideological indoctrination may have contributed to the differences: citizens of the East were not exposed to the criticism of technology that in the West originated in the civil society and led to protest movements against nuclear power, biotechnology and the chemical industry.

\section{Goodbye 'ivory tower': Scientists and science organisations}

In the 1960s, journalists, politicians and communication scholars in West Germany diagnosed a societal need for public communication of science and also identified an apparent reluctance of scientists to leave their 'ivory tower'. However, the first German survey of scientists' attitudes towards the mass media and their interactions with journalists by Jens Krüger in 1984 
showed instead that a majority of professors at the University of Mainz were actually talking to journalists. They reported positively or neutrally about their experiences with the media and had a positive attitude towards public communication (Krüger, 1985, 1987). Later surveys among a more diverse sample of German scientists confirmed this initial finding (Strömer, 1999; Peters et al., 2009; Pansegrau et al., 2011; Peters et al., 2012). There are hardly formal incentives for German scientists to go to the media, but many perceive the professional benefits of public visibility. The public relations departments of universities and other research centres generally motivate scientists for public communication, and scientists recognise that their organisations want them to communicate with the public (Marcinkowski et al., 2014; Peters, 2019). Since 2000, the German Research Foundation (Deutsche Forschungsgemeinschaft, DFG) has awarded an annual 'communicator prize' to a scientist for excellence in public communication.

To improve the public communication skills of scientists, Walter Hömberg organised the first German media training seminars for scientists at the Catholic University of Eichstätt in 1990 (Hömberg, 1998) and other organisations such as the Forschungszentrum Jülich [Research Centre Jülich] followed (Göpfert and Peters, 1992). Today, media training for scientists is offered on a regular basis by several organisations in Germany such as the Nationales Institut für Wissenschaftskommunikation [National Institute for Science Communication] in Karlsruhe. In a recent survey, 21 per cent of a sample of 240 German researchers from natural sciences and engineering said that they had received some form of communication training (Lo, 2016, p. 133).

Parallel to the individual media contacts of scientists, mostly initiated by journalists, several science organisations had established policies and units for public communication in the 1960 s or even before. These included universities as well as the large non-university research institutions such as the Max-Planck Society, Fraunhofer Society, Helmholtz Association and Leibniz Society. The association of German universities (Hochschulrektorenkonferenz, HRK) recommended the establishment of press offices at German universities in the 1950s and 1960s (Bühler et al., 2007) and, in 1969, the association of university press officers (Bundesverband Hochschulkommunikation) was founded. By the 1970s, the majority of German universities had installed press offices or at least assigned staff responsible for public communication. The rising public awareness of the risks of science and technology and the association of universities with student riots, a steady growth of the academic education sector and the high unemployment rate of academics (Tonnemacher, 1982) forced universities to strengthen their communication activities. In addition, 
there was growing competition between science organisations for public funding. Consequently, the communication functions of universities and other research organisations were professionalised and expanded in the 1980s.

According to the rectors' conference, the main objective of university communication was to support communication within the university and to be in dialogue with the public sphere through media relations. Further activities such as science festivals and other events were only apparent from the 1990s. In 1995, the HRK released new recommendations for public communication that emphasised it as a core responsibility of university management. The recommendations emphasised that public communication should pursue the universities' interests. Most important objectives were to sustain autonomy for research and teaching but also to secure research funding in an unfavourably changing social environment (Hochschulrektorenkonferenz, 1995 , p. 2).

\section{Public controversies over techno-sciences}

Since the beginning of the 1970s, big public controversies over nuclear power, biotechnology and environmental issues played out in West Germany as in many other European countries (e.g. Kepplinger et al., 1991; Kliment, 1994; Bauer, 2014). Science was involved in two roles: as technology developer and as provider of scientific expertise for the assessment of risks and benefits. Scientific expertise and counter-expertise were used as political resources in these controversies (e.g. Peters, 1994).

Acceptance of modern technologies was one of the strong motivators for government and industry to engage in or sponsor science communication activities-for example, nuclear power and biotechnology. Industry and nuclear research institutes cooperated in the Informationskreis Kernenergie [Nuclear Energy Information Group]. It was founded in 1975 to provide public information about nuclear power, energy policy and safety aspects. Public information groups were established at research institutes dealing with nuclear power: Kernforschungsanlage Jülich (KFA), for example, tried to raise the knowledge level of citizens through activities including popular books, public talks, information seminars for journalists and teachers and the provision of scientific experts for lectures at schools. These communication initiatives generally relied on 'deficit model' assumptions: that acceptance problems resulted from a lack of knowledge or from misinformation about a technology, and that overcoming acceptance problems was possible by replacing public ignorance with scientifically sound information. 
Recognising that information alone was ineffective for overcoming acceptance problems, in 1975 the Ministry for Research and Technology (BMFT) offered an open citizen dialogue on nuclear energy (Bürgerdialog Kernenergie) (Hauff, 1977). Anticipating the later development of the consensus conference model, experiments with citizen participation in energy planning explored citizens' energy-related preferences. So-called 'planning cells' were used to summarise citizens' informed opinions for policymakers in a 'citizen expert report' (Dienel and Garbe, 1985; Renn et al., 1984). But these efforts had no significant consequences for public policy or public acceptance. In the end, the German phasing-out policy on nuclear energy resulted from long-lasting public protests, often involving violence and civil disobedience, and 'supported' by increasingly professionalised counter-expertise and the shockwaves of the Chernobyl disaster in 1986 and the Fukushima disaster in 2011. Both de-legitimised pro-nuclear positions in the public discourse (Arlt and Wolling, 2014).

Concerns about a specific German hostility towards technology (Technikfeindlichkeit) spread in the 1970 and 1980s, underpinned by Elisabeth Noelle-Neumann and her influential polling institute Institut für Demoskopie Allensbach, whose time-series data showed a decay of positive attitudes towards technology among the German population (e.g. NoelleNeumann and Hansen, 1988). Biased and negative media reporting of science and technology was often assumed as the cause for this attitude change. In 1986, BMFT created a research program on public acceptance and media impact (Technikakzeptanz und Medienwirkungen) that led to a number of studies about public opinion of science and technology. In his famous (and controversial) study 'Artificial Horizons', Kepplinger $(1989,1992)$ presented empirical evidence for the hypothesis that biased media reporting on the risks and benefits of technologies caused changes in public opinion towards the negative. However, other researchers in the program disagreed with the idea of a particular German hostility towards science and technology and concluded rather that the German public had ambivalent attitudes, with clearly negative attitudes restricted to a few specific techno-sciences such as nuclear power or food biotechnology (Jaufmann and Kistler, 1988; Jaufmann et al., 1989; Jaufmann and Kistler, 1991).

\section{The German PUSH in science communication}

In the years before the EXPO 2000 in Hanover, the big German science associations together with the BMFT (now the Ministry of Education and Research, BMBF) planned the German contribution to the exhibition. Probably for the first time, high-level talks about the public communication 
of science took place between top research managers and representatives of the government. In the context of these talks the idea of an innovative 'relaunch' of science communication was born, different from communication via the mass media that so far had dominated the German discussion about science communication. The action program Public Understanding of Science and Humanities (PUSH) was launched by a memorandum on the dialogue between science and society that was signed by the head of Stifterverband (the organisation that provided money for the program) and the heads of the large German science associations (Stifterverband, 1999). It called for increased efforts in science communication and the provision of incentives and support for scientists wanting to interact with the public. A call for science communication initiatives was issued and grants for model projects were awarded through the action program.

For a second time (after the adoption of US science journalism in the 1980s), an Anglo-Saxon model set an example for science communication efforts in Germany. ${ }^{3}$ While clearly adopting the general ideas of the public engagement approach with its focus on dialogue, involvement, participation and direct experience of science and scientists, the initiators decided to stick to the traditional 'Public Understanding of Science' label-not even translating it into German-but supplementing it with 'Humanities' to account for the German insistence on the unity of the academic world (obvious in the German term Wissenschaft that covers the sciences, social sciences and humanities).

With respect to scientific actors in public communication, the consequences of the relaunch of science communication marked by the PUSH initiative and the availability of new online channels of addressing larger public audiences without journalistic mediation were fourfold:

(1) The founding of a quasi-agency Wissenschaft im Dialog (WiD) in charge of the national coordination of science communication initiatives and initiates, and which encourages and coordinates many activities. ${ }^{4}$ Controlled by the big science associations and some foundations, it also collaborates with BMBF. Communication activities of WiD include mobile science exhibitions, science cafés and debates. From 2000-12 WiD oversaw the 'science summers', the German version of science festivals taking place in different cities. Since 2003 it has organised the 'science years' on behalf of the BMBF. While the German

3 The importance of the Anglo-Saxon dialogue model for Germany is obvious from the schedule of the initial PUSH symposium. The program started with sessions 'Example Great Britain' and 'Example USA', each country being represented by two keynote speakers, and then moved on to 'Plans for Dialogue in Germany' (Stifterverband, 1999). German science communication scholars, with their almost exclusive focus on science journalism, were largely ousted from the relaunch of science communication.

4 See www.wissenschaft-im-dialog.de/en/about-us/. 
science years resemble national science weeks in other countries, their activities are not limited to a particular week. Each science year is devoted to a particular discipline or topic, e.g. chemistry (2003), humanities (2007), digital society (2014) and artificial intelligence (2019). WiD also operates online platforms for citizen science and crowd-funding projects; offers science communication summer schools for scientists; organises annual conferences for science communication practitioners (Forum Wissenschaftskommunikation); and conducts the Science Barometer (Wissenschaftsbarometer), an annual survey of the public image of science in Germany. One focal instrument is the online platform Wissenschaftskommunikation.de, which offers opinion pieces, interviews, debates and summaries for actual trends and issues from the field of science communication. ${ }^{5}$ Within the almost 20 years of its existence, WiD has developed from a mere event organisation into a major player in the field and considers itself a driving force and think tank for science communication in Germany and beyond (Wissenschaft im Dialog, 2017).

(2) In general, organisational science communication has become tremendously professionalised within the last 20 years after the PUSH memorandum. A survey among university public information officers by Leßmöllmann et al. (n.d. [2017]) showed that university PR is an expanding field. Respondents to the survey believe it will become even more important in the next years and expect budgets and staffing to grow. While this relates to all fields of science communication from online events to media relations, the latter is still considered one of the most important activities of university science communication (Lehmkuhl, 2019). Media relations activities (e.g. sending out press releases) are still very important and even on the rise (Serong et al., 2017). Parallel to relations with traditional media, the importance of online media is rising in organisational PR. All universities and research organisations use a website and further online channels, such as blogs, Facebook, Twitter and Instagram to address their stakeholders (Metag and Schäfer, 2019).

(3) The media-targeted efforts of science organisations have been supplemented with a portfolio of activities aiming at different target groups and serving different goals from science education to participation in research and science policy. Science organisations participate in activities coordinated by WiD such as the science summers and science years mentioned above. They also organise local activities on their own or in cooperation with others such as 'long nights' of science, open days, 'science slams', citizen science, children's universities and school labs at research institutions (Weingart et al., 2007; Schneider, 2012; Fähnrich, 2017).

5 This platform is a joint activity of $\mathrm{WiD}$, the German Nationales Institut für Wissenschaftskommunikation [National Centre for Science Communication], and the science communication unit at the Karlsruhe Institute of Technology. 


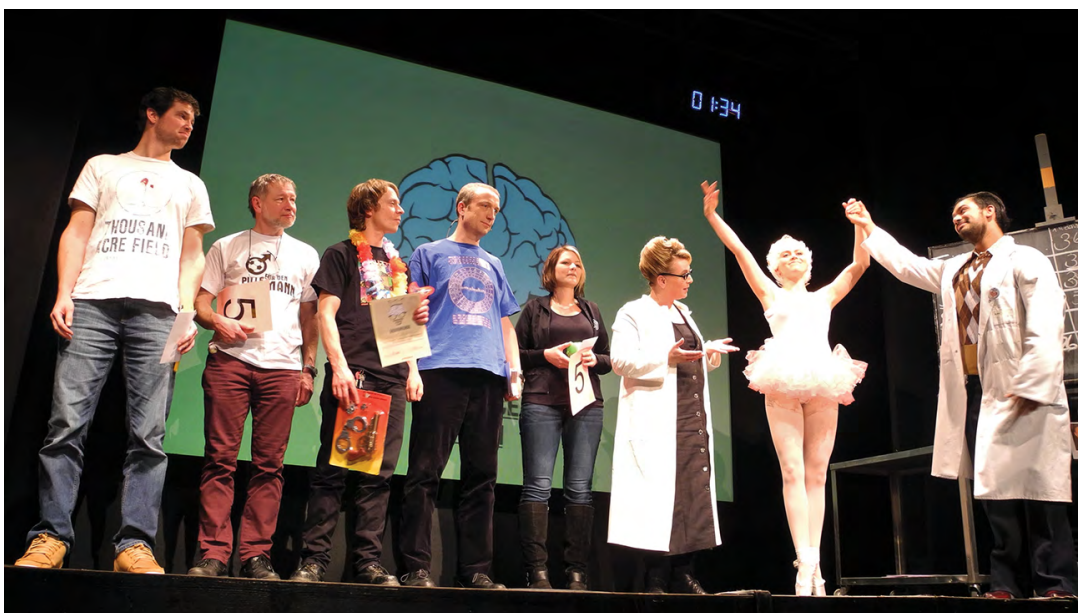

Figure 14.1: A scene from a so-called 'science slam'; this one took place in 2014 in the Theatre of Marburg. Scientists have a few minutes to talk about a subject of their choice. A jury from the audience rates their performance and determines a winner. Science slams are usually organised as humorous events.

Source: H. P. Peters (used with permission).

Yet there are some concerns that the engagement activities implemented after the PUSH memorandum lack concrete aims and target groups; are largely manifestations of one-way knowledge dissemination by scientists; only preach to the converted; and avoid direct dialogue between scientists and citizens about controversial issues (Schnabel, 2008). In their analysis of science communication in Germany for the German Ministry of Education and Research, Weingart et al. (2007) similarly conclude that while the efforts successfully initiated science communication and established it as a task area for science and politics, they did not succeed in starting a societal dialogue, and reached only those already interested in science.

(4) For a long time, individual scientists communicated with the public mainly through their interactions with journalists. The development of a rich infrastructure of event-based interactions with the public, expansion of organisational public relations and the more widespread access of the general public to websites, blogs and social media, increased their options. The number of opportunities for them to meet the public grew as organisers of science communication events, in particular the PR departments of their own universities or other science organisations, offered more invitations to scientists to participate. Scientists motivated for proactive communication could easily use personal websites, blogs, Facebook, Twitter, Wikipedia or YouTube to address the public directly, and a significant proportion of them have begun to use these online channels (Lo, 2016). 


\section{Online communication}

The paradigm shift towards more dialogical forms of science communication coincided with the development of the internet from a specialised communication infrastructure to a general one. Between 1998 and 2003 the proportion of the German population at least occasionally using the internet rose from about 10 per cent to 54 per cent (Projektgruppe ARD/ZDFMultimedia, 2017). This development created the principal opportunity for dialogic communication between scientific communicators and citizens without journalistic mediation, thus providing science a means to implement the new public engagement paradigm not only through events and face-toface interactions but also online.

Yet compared with other countries, online social media are generally less important than other information media in Germany, although the percentage of the population with access to the internet is similar to that of the United States, for example (Hasebrink and Hölig, 2013; Pew Research Center, 2016; Newman et al., 2017). Germans would routinely use the internet when seeking specific information, e.g. about a health problem. For news in general and for science news in particular they still prefer journalistic media, including their online sites. This has an impact on scientists' beliefs, preferences and behaviour regarding the use of online communication with the public. Allgaier et al. (2013) have shown that German neuroscientists have assessed the impact of blogs and social media on science policymaking and public opinion as being lower than their US colleagues. In a survey of scientists in Germany, Taiwan and the United States, Lo (2016) found that Germany ranked lowest among these countries with respect to scientists' actual use of personal websites, blogs and social networks for communication with the public.

The German science academies have started to deal with the challenges of science communication in the digital age and its consequences for the science-society interface. They established a joint working group Relationship of Science, Public Sphere and Media (2015-17) to study the challenges arising from the digitalisation of communication. The working group has published a number of recommendations (acatech, 2017; Weingart et al., 2017) and the topic remains on the agenda. In 2018, the Berlin-Brandenburg Academy of Sciences and Humanities created an interdisciplinary research group to explore the 'Implications of Digitisation for the Quality of Science Communication'. ${ }^{6}$

6 See www.bbaw.de/en/research/wissenschaftskommunikation. 


\section{Science museums and science centres}

Germany has a long tradition and rich landscape of institutions of informal learning related to science and technology including museums that exhibit artefacts from science, technology, medicine and nature (including their history); and hands-on science centres that focus on interactivity with the visitors. ${ }^{7}$ The latter are of more recent origin. Planetariums and public astronomical observatories complement the list of institutions for science education. The German report of the Monitoring Policy and Research Activities on Science in Society in Europe (MASIS) initiative estimates that 'over 1,000 science centres and museums on science and technology, natural history and natural science provide access to their collections and attracted over 24 million visitors in 2009' (Grunwald, 2011, p. 63). ${ }^{8}$

Since about the mid-1990s approximately 25 science centres in the modern sense-i.e. educational, entertaining and hands-on-have opened their doors in Germany. ${ }^{9}$ Among these science centres are very small institutions with only a few thousand visitors per year, but also large centres that count several hundred thousand visitors each year. The Universum Bremen, founded in 2000, is the older of the two largest science centres in Germany (about 215,000 visitors in 2017). The permanent display is supplemented by special exhibitions and events such as science shows, science theatres and talks. The centre engages in collaborations with schools. In 2005 the Phaeno, another large science centre (about 245,000 visitors in 2016), opened in Wolfsburg in a building that received much attention because of its spectacular architecture. The Mathematikum Giessen is a mid-size science centre (about 150,000 visitors per year) with a clear focus on mathematics and addressing a broad audience. It opened in 2002.

Final examples of German hands-on science centres are the Phänomenta centres, small to mid-size centres in four German cities: Lüdenscheid, Bremerhaven, Flensburg, Peenemünde. The first of these centres opened in 1993 in Flensburg. It was based on interactive exhibits that had been displayed in the University of Flensburg since 1986 (Kiupel, 1998). While these four centres have developed locally and independently of each other, they have built a network and created a common brand.

7 This section on science museums and science centres is adopted from an unpublished expert opinion written for the PLACES project (Peters, 2013).

8 Note that in accordance with the broad German definition of Wissenschaft, these figures include museums on history and archaeology.

9 A list of German science centres can be found at www.science-museum.de. 


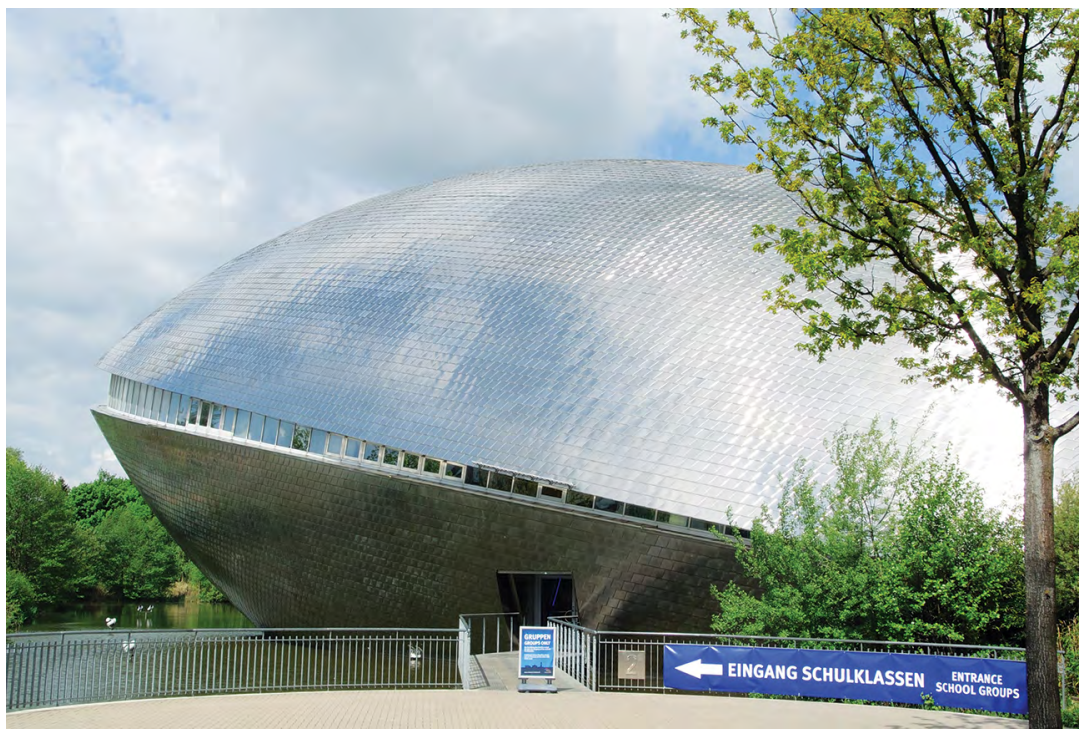

Figure 14.2: Universum Bremen, the first 'large' modern science centre in Germany.

Source: H. P. Peters (used with permission).

\section{The role of politics in the development of science communication}

In a keynote at the 1977 annual meeting of the DFG, the then German Chancellor Helmut Schmidt emphasised science's responsibility towards a democratic society and urged German scientists to become publicly visible. He coined the widely quoted term of a Bringschuld, i.e. a duty of individual scientists and researchers to actively engage with the public, and not to delegate that task to public information departments or science journalists (Schmidt, 1977, 2005). He also stated that public visibility of science helps to defend public funding of science against competing demands of other stakeholders.

Schmidt's call was preceded by earlier discussions of the relationship of science and democratic society. For example, the political scientist and socialdemocratic politician Ulrich Lohmar had pointed to the challenges of the 'productive force science' for a democratic society. Lohmar emphasised the responsibility of the media for making science transparent for citizens and enabling a critical public discourse about science. He diagnosed deficits of journalism in this respect (Lohmar, 1972). 
German governments were and certainly are interested in a science-attentive, science-literate and science-friendly German public. However, they have largely remained in the background. Whereas there has been encouragement and funding for science communication and research on it, the leading role has been left to scientific organisations and private foundations. One of the important exceptions is the (failed) citizen dialogue on nuclear power mentioned above.

The core interest of the German government in PCST (probably like that of most governments worldwide) is based on the beliefs that good science communication and public engagement with science will foster technological innovation and thus contribute to the economic competitiveness and social welfare of the country. It is thus no surprise that the German High-Tech Strategy includes a chapter on science communication and participation (BMBF, 2018).

Another motivation appears in the discussion of science communication by politicians: the idea of a democratisation of science and science policy by citizen participation, quite similar to the goals stated in the UK House of Lords Select Committee on Science and Technology (2000) report and probably influenced by it. The goal to enable public participation in science and science policy is evident-for example, in the coalition contract between two major political parties in Germany (the conservative CDU/CSU and the liberal SPD) beginning in 2013 (Koalitionsvertrag, 2013, p. 151). The parties agreed to involve citizens in the discussion of future projects and the shaping of the science agenda and to develop new forms of citizen participation and science communication. In 2016, BMBF issued a position paper on the participation of civil society in science and science policy (BMBF, n.d. [2016]). The benefits of citizen participation are seen in increased interest and trust in science and improved legitimacy of decisions about science policy. This may be seen as just another strategy to create 'acceptance' for science and technology. But the position paper also emphasises the role of civil society in shaping science and technology policy, and points to the large potential for citizens' knowledge to be utilised in citizen science projects and by crowd-sourcing.

In 2015-17, the BMBF experimented with citizen participation in a series of so-called ZukunftsForen [Future Forums] dealing with innovation in health care, the sharing economy, digitalisation and technologies transforming the working environment. Each forum combined a public opinion survey, workshops and a discussion of citizens and representatives from science and politics with the responsible minister. However, it is not obvious whether and how the results of the citizen consultation had an impact on research and innovation policy. 
As mentioned above, foundations have played an important role in the development of science communication in Germany as funders and also initiators of programs and activities. Although politicians assumed that public communication of science is both important and deficient, for a long time they did not consider 'promotion' of science communication as a legitimate field of political activity but saw it rather as a genuine responsibility of scientists and of the media. We suspect that the reluctance of the government to intervene in the public communication of science may be a consequence of the experience with Nazi propaganda, which delegitimised direct government influences on media and public communication in the post-war era. We believe that this reservation of the German government created an empty space that was filled by activities of charitable foundations.

\section{Academic institutionalisation of science communication}

Although interdisciplinary perspectives from sociology (e.g. Weingart, 2001), psychology (cf. Bromme and Kienhues, 2017) and even philosophy (Spinner, 1985) play a significant role in German science communication research, the academic institutionalisation of the field has taken place predominantly in communication and media studies (Bonfadelli et al., 2017). The field of science and technology studies, an important context for science communication in other European countries (e.g. Horst et al., 2017), is less significant in Germany. The development of science communication research in Germany can be regarded as a response to the perceived deficient status of science communication practice. Since the 1970s, several workshops on science and the media have enabled a discourse between scientists, science journalists, public information officers and communication scholars. The Center for Interdisciplinary Research (Zentrum für interdisziplinäre Forschung, $\mathrm{ZiF}$ ) at the University of Bielefeld established an interdisciplinary research group, Science and Journalism in 1974 (Hömberg, 1974), which led to a number of early studies on science and the media (e.g. Roloff and Hömberg, 1975; Depenbrock, 1976; Hellmann, 1976). These initiatives and activities are glimpses of a comprehensive landscape of workshops, roundtables, reports and declarations addressing the issue of science and the media, starting in the 1970s or even before.

It is interesting to note that the public communication of the social sciences was included in this discussion early on (e.g. Wissenschaftszentrum Berlin, 1976; Hömberg, 1978; Peters, 1982). However, with some exceptions (e.g. Weßler, 1995; Fähnrich and Lüthje, 2017), the focus of science communication research in Germany was and still is on the natural sciences and related topics such as climate change. 
Academic science communication programs in Germany are still rare and only four universities have degree programs specifically related to science communication in the broader sense. The Technical University of Dortmund offers bachelor and master's programs in 'science journalism' aimed at training future science journalists; the Karlsruhe Institute of Technology offers bachelor and master's programs in 'science - media - communication', preparing graduates for a more diverse spectrum of functions in science communication. Two bachelor programs on 'science communication \& bionics' (English-speaking) and 'technical journalism/PR' exist at the Rhine-Waal University of Applied sciences in Kleve and the Bonn-Rhein-Sieg University of Applied Sciences in St Augustin, respectively. Ten full professors with explicit appointments for science communication are currently teaching at nine universities, and several more are interested in science communication although their chairs do not denote such a specialisation. Science communication can be part of the curriculum of some general communication or interdisciplinary degree programs.

While academic institutes for science communication only evolved after 1990, the topic itself had previously been the subject of many doctoral dissertations and other academic theses (cf. the documentation by Krüger and Flöhl, 1982). The first and (to date) only relevant temporary postgraduate research program leading to doctoral theses on science communication was the DFG graduate program 'On the Way into the Knowledge Society' at the University of Bielefeld in 2002-11. However, the strong majority of doctoral dissertations are done outside formal postgraduate programs. In the past 15 years the DFG, $\mathrm{BMBF}$ and the Volkswagen Foundation have funded several research programs on science communication, leading to dozens of projects in which doctoral students were employed as junior researchers and given the opportunity to conduct their $\mathrm{PhD}$ research related to the projects. There is a growing number of young researchers who consider themselves 'science communication scholars', contributing to national and international science communication conferences such as the PCST conferences and publishing in international science communication journals. While several general communication journals are published in Germany that also accept articles on science communication, there is no dedicated science communication journal.

An important step in the academic institutionalisation of science communication research in Germany was the creation of a science communication branch (Fachgruppe Wissenschaftskommunikation) of the German communication association (DGPuK) in 2012. ${ }^{10}$ It organises annual conferences (Schäfer et al., 2015; Ruhrmann et al., 2017; Hagen et al., 2018)

10 See www.dgpuk.de/en/science-communication.html. 
and supports exchanges among scholars in the field. In 2019, the branch had about 120 members from universities and research organisations in Germany and also from Switzerland and Austria.

\section{Current issues}

While for decades German scientists and science organisations were called to increase their public communication efforts, there is now growing concern about possible negative implications of scientists' and science organisations' increasing interest of being visible in the public sphere (Weingart, 2012; Marcinkowski and Kohring, 2014). It is feared that the 'medialisation of science' (Weingart, 2012) may have negative impacts on the quality of public communication. In order to get the attention of journalists and/or a public audience, scientists and public information officers may be tempted to hype their messages. A second possibility is that a strong media orientation of scientists and science organisations may result in the partial replacement of genuine scientific criteria with criteria of media attention that are then not only used in public communication but also within science. According to the medialisation thesis, decisions about research, the distribution of resources, the interpretation of findings and scholarly publication may be influenced by anticipation of public responses, thereby subtly compromising the autonomy of science, which is highly valued in Germany. In the end the quality of scientific knowledge itself may suffer. The medialisation of science hypothesis has received a lot of interest among science communication scholars and has stimulated several $\mathrm{PhD}$ theses and research projects.

A working group of the German science academies has responded to the temptations of public visibility and other challenges of science communication with the development of guidelines urging scientists and science organisations to communicate with the public in line with scientific responsibility. The guidelines also emphasise the importance of independent quality science journalism (acatech, 2014). Similarly, an influential group of university press officers (Siggener Kreis) has issued guidelines for ethical science PR (Bundesverband Hochschulkommunikation/Wissenschaft im Dialog, 2016), calling for self-restriction in using the increased power of science PR.

As Davies and Horst (2016) have noted, the 'ecosystem of science communication' is changing and diversifying. The above-mentioned German meta-discourses on science communication reflects the empirical and normative uncertainties about the consequences of ongoing changes caused by the increasingly strategic orientation of communicators, the growing importance of online communication and a focus on public engagement as a model for science communication. 
Germany has its own history of science popularisation by scientists and the mass media, but it has also been open to adopting approaches from the Anglo-Saxon countries. The first of these adoptions-learning from science journalism in the United States-had the goal of strengthening the role of journalism as mediator between science and the public. The second adoption-the public engagement approach with its focus on direct interaction and dialogue with citizens_created an alternative channel for public communication and thus reduced science communicators' dependency on science journalism. We are quite convinced that in Germany journalism is still important in the public communication of scientific knowledge and the critical surveillance of science as a social system, but that communicators from science and government believe in the advantage of public engagement as a means to increase public appreciation and trust. An open question is whether public engagement as it is currently implemented in Germany truly can contribute to a re-negotiation of the science-in-society relationship or serves, in effect, as a surrogate in that respect.

The options of science communicators multiplied, new niches arose and were colonised, priorities and resources of science communicators were re-allocated. Science communicators are currently adapting public communication to the new ecosystem. Changes in the ecosystem of science communication also imply changes in the roles of communicators and shifts in the distribution of power between different actors. Science communicators and scholars in Germany pursue a critical discourse not only about the 'efficiency' of communication in terms of impact, but also about the responsible use of options and power in the changed ecosystem of science communication.

\section{Acknowledgements}

Peter Weingart, Jens Krüger, Toss Gascoigne and two anonymous reviewers provided valuable comments on a previous version of our chapter. We gratefully acknowledge their criticism and suggestions that guided us in our revision.

\section{References}

acatech. (2014). On Designing Communication between the Scientific Community, the

Public and the Media. München: National Academy of Science and Engineering. acatech. (2017). Social Media und digitale Wissenschaftskommunikation. Analyse und

Empfehlungen zum Umgang mit Chancen und Risiken in der Demokratie. München: National Academy of Science and Engineering. 
Allgaier, J., Dunwoody, S., Brossard, D., Lo, Y.-Y. and Peters, H. P. (2013). Journalism and social media as means of observing the contexts of science. BioScience, 63(4), 284-7. doi.org/10.1525/bio.2013.63.4.8.

Arlt, D. and Wolling, J. (2014). Fukushima-Effekte in Deutschland? Die Reaktorkatastrophe als Ursache von Veränderungen in der Berichterstattung und in der öffentlichen Meinung über die Atomenergie. In J. Wolling and D. Arlt (eds), Fukushima und die Folgen. Medienberichterstattung, Öffentliche Meinung, Politische Konsequenzen (pp. 269-96). Universitätsverlag Ilmenau, Ilmenau.

Ausejo, E. (1994). The window case of science: the associations for the advancement of science and the birth of scientific congresses in Western Europe. Archives Internationales d'Histoire des Sciences, 44(133), 338-71.

Bauer, M. W. (2014). Atoms, Bytes and Genes. Public Resistance and Techno-Scientific Responses. London: Routledge. doi.org/10.4324/9781315775999.

BMBF. (n.d. [2016]). Grundsatzpapier des Bundesministeriums für Bildung und Forschung zur Partisipation. Berlin: Ministry of Education and Research. Retrieved from www.zukunft-verstehen.de/download_file/view/379/437.

BMBF. (2018). Forschung und Innovation für die Menschen. Die Hightech-Strategie 2025. Berlin: Ministry of Education and Research.

Bonfadelli, H., Fähnrich, B., Lüthje, C., Milde, J., Rhomberg, M. and Schäfer, M. S. (2017). Das Forschungsfeld Wissenschaftskommunikation. In H. Bonfadelli, B. Fähnrich, C. Lüthje, J. Milde, M. Rhomberg and M. S. Schäfer (eds), Forschungsfeld Wissenschaftskommunikation. Wiesbaden: Springer VS. doi.org/ 10.1007/978-3-658-12898-2.

Bromme, R. and Kienhues, D. (2017). Gewissheit und Skepsis: Wissenschaftskommunikation als Forschungsthema der Psychologie (Editorial). Psychologische Rundschau, 68(3), 167-71. doi.org/10.1026/0033-3042/a000359.

Bühler, H., Naderer, G., Koch, R. and Schuster, C. (2007). Hochschul-PR in Deutschland. Ziele, Strategien und Perspektiven. Wiesbaden: Deutscher Universitäts-Verlag.

Bundesverband Hochschulkommunikation/Wissenschaft im Dialog. (2016). Leitlinien zur guten Wissenschafts-PR. Retrieved from www.wissenschaft-im-dialog.de/ fileadmin/user_upload/Trends_und_Themen/Dokumente/Leitlinien-guteWissenschafts-PR_final.pdf.

Commission of the European Community. (1993). Biotechnology and genetic engineering. What Europeans think about it in 1993. Survey conducted in the context of Eurobarometer 39.1. Retrieved from ec.europa.eu/commfrontoffice/ publicopinion/archives/ebs/ebs_080_en.pdf.

Davies, S. and Horst, M. (2016). Science Communication. Culture, Identity and Citizenship. London: Palgrave Macmillan. 
Depenbrock, G. (1976). Journalismus, Wissenschaft und Hochschule. Bochum: Brockmeyer.

Dienel, P. C. and Garbe, D. (1985). Zukünftige Energiepolitik. Ein Bürgergutachten. München: High Tech Verlag.

European Commission. (2005). Europeans, Science and Technology. Eurobarometer 2005. Brussels: European Commission.

Fähnrich, B. (2017). Wissenschaftsevents zwischen Popularisierung, Engagement und Partisipation. In H. Bonfadelli, B. Fähnrich, C. Lüthje, J. Milde, M. Rhomberg and M. S. Schäfer (eds), Forschungsfeld Wissenschaftskommunikation (pp. 165-82). Wiesbaden: Springer. doi.org/10.1007/978-3-658-12898-2_9.

Fähnrich, B. and Lüthje, C. (2017). Roles of social scientists in crisis media reporting: The case of the German populist radical right movement PEGIDA. Science Communication, 39(4), 415-42. doi.org/10.1177/1075547017715472.

Fähnrich, B., Metag, J., Post, S. and Schäfer, M. S. (eds) (2019). Forschungsfeld Hochschulkommunikation. Wiesbaden: Springer VS. doi.org/10.1007/978-3658-22409-7.

Faulstich, P. (2006). Öffentliche Wissenschaft. In P. Faulstich (ed.), Öffentliche Wissenschaft. Neue Perspektiven der Vermittlung in der wissenschaftlichen Weiterbildung (pp. 11-32). Bielefeld: Verlag. doi.org/10.14361/9783839404553.

Fischer, H.-D. (1976). Probleme der 'Vermarktung' von Wissenschaft durch Massenmedien. Aus Politik und Zeitgeschichte, B44, 9-34.

Fox, F. (2012). Practitioner's perspective: The role and function of the Science Media Centre. In S. Rödder, M. Franzen and P. Weingart (eds), The Sciences' Media Connection - Public Communication and its Repercussions (pp. 257-70). Dordrecht, NL: Springer. doi.org/10.1007/978-94-007-2085-5_13.

Göpfert, W. (ed.) (2006). Wissenschaftsjournalismus. Ein Handbuch für Ausbildung und Praxis. Berlin: Econ.

Göpfert, W. and Bader, R. (eds) (1998). Risikoberichterstattung und Wissenschaftsjournalismus - Risk Communication and Science Reporting. Tagungsbericht zum 4. Colloquium Wissenschaftsjournalismus. Stuttgart: Schattauer Verlag.

Göpfert, W. and Peters, H. P. (1992). Konzept einer 'Sommerschule Wissenschaftsjournalismus' und Erfahrungen bei der Realisierung. Publizistik, 37(1), 118-20.

Göpfert, W. and Schanne, M. (1998). Das Förderprogramm Wissenschaftsjournalismusder Robert Bosch Stiftung GmbH: Evaluation. Berlin and Zurich: Zusammenfassender Bericht. Retrieved from www.polsoz.fu-berlin.de/kommwiss/arbeitsstellen/ wissenskommunikation/media/bericht.pdf. 
Grabowski, K. H. (1982). Strukturelle Probleme des Wissenschaftsjournalismus in aktuellen Massenmedien. Eine soziologisch-kommunikationswissenschaftliche Untersuchung. Bochum: Brockmeyer.

Gruhn, W. (1979). Wissenschaft und Technik in deutschen Massenmedien: Ein Vergleich zwischen der Bundesrepublik Deutschland und der DDR. Erlangen: Deutsche Gesellschaft für zeitgeschichtliche Fragen e.V.

Grunwald, A. (2011). Monitoring Policy and Research Activities on Science in Society in Europe (MASIS). National Report, Germany. Retrieved from rritrends.res-agora. eu/uploads/1/MASIS_Germany.pdf.

Hagen, L., Lüthje, C., Ohser, F. M. and Seifert, C. (eds) (2018). Wissenschaftskommunikation: Die Rolle der Disziplinen. Baden-Baden: Nomos. doi.org/10.5771/9783845276427.

Hasebrink, U. and Hölig, S. (2013). Lagging behind or choosing a different path? Information behaviour in Germany. In N. Newman and D. A. L. Levi (eds), Reuters Institute Digital News Report 2013: Tracking the Future of News (pp. 81-83). Oxford: University of Oxford, Reuters Institute for the Study of Journalism.

Hauff, V. (1977).Zwischenbilanzzum Bürgerdialog Kernenergie. Sozialdemokratischer Pressedienst, 28. Oktober 1977, pp. 1-2. Retrieved from gateway-bayern.de/ BV027894691.

Hellmann, M. (1976). Medisinberichterstattung in der Presse. Deutsches ÄrzteblattÄrztliche Mitteilungen, 73(45), 1-7.

Hettwer, H., Lehmkuhl, M., Wormer, H. and Zotta, F. (eds) (2008). WissensWelten. Wissenschaftsjournalismus in Theorie und Praxis. Gütersloh: Verlag Bertelsmann Stiftung.

Himpsl, F. (2017). 'Third Mission'. Forschung, Lehre - und was noch? Deutsche Universitätszeitung, no. 5/2017. Retrieved from www.duz.de/beitrag/!/id/428/ forschung-lehre-und-was-noch.

Hochschulrektorenkonferenz. (1995). Zur Öffentlichkeitsarbeit der Hochschulen. Empfehlungen des 176. Plenums. Bonn.

Hömberg, W. (1974). Wissenschaft und Journalismus: Interdisziplinäres Forschungsprojekt an der Universität Bielefeld. Information und Meinung, 5, $30-31$.

Hömberg, W. (1978). Soziologie und Öffentlichkeit. Soziologie, 1, 5-23.

Hömberg, W. (1980). Glashaus oder Elfenbeinturm? Zur Entwicklung und zur Lage der Wissenschaftskommunikation. Aus Politik und Zeitgeschichte, B28, 37-46.

Hömberg, W. (1990). Das verspätete Ressort. Die Situation des Wissenschaftsjournalismus. Konstanz: Universitätsverlag. 
Hömberg, W. (1998). Keine Angst vor Journalisten - Medientraining für Wissenschaftler. In W. Göpfert and R. Bader (eds), Risikoberichterstattung und Wissenschaftsjournalismus - Risk Communication and Science Reporting. Tagungsbericht zum 4. Colloquium Wissenschaftsjournalismus (pp. 145-54). Stuttgart: Schattauer Verlag.

Horst, M., Davies, S. R. and Irwin, A. (2017). Reframing Science Communication. In U. Felt, R. Fouché, C. A. Miller and L. Smith-Doerr (eds), The Handbook of Science and Technology Studies (pp. 881-907). Cambridge, MA: MIT Press.

Humboldt, W. v. (1964). Werke in fünf Bänden: Band IV: Schriften zur Politik und zum Bildungswesen. Darmstadt: Wissenschaftliche Buchgesellschaft.

Jaufmann, D. and Kistler, E. (eds) (1988). Sind die Deutschen technikfeindlich? Opladen: Leske + Budrich. doi.org/10.1007/978-3-322-95585-2.

Jaufmann, D. and Kistler, E. (eds) (1991). Einstellungen zum technischen Fortschritt. Technikakzeptanz im nationalen und internationalen Vergleich. Frankfurt-Main, New York: Campus Verlag.

Jaufmann, D., Kistler, E. and Jänsch, G. (1989). Jugend und Technik: Wandel der Einstellungen im internationalen Vergleich. Frankfurt-Main, New York: Campus Verlag.

Kepplinger, H. M. (1989). Künstliche Horizonte: Folgen, Darstellung und Akzeptanz von Technik in der Bundesrepublik. Frankfurt-Main, New York: Campus Verlag.

Kepplinger, H. M. (1992). Artificial horizons. How the press presented and how the population received technology in Germany from 1965-1986. In S. Rothman (ed.), The Mass Media In Liberal Democratic Societies (pp. 147-76). New York: Paragon House.

Kepplinger, H. M., Ehmig, S. C. and Ahlheim, C. (1991). Gentechnik Im Widerstreit: Zum Verhältnis Von Wissenschaft Und Journalismus. Frankfurt-Main, New York: Campus Verlag.

Kiupel, M. (1998). Phänomenta - where physics is fun! Paper presented at the 5th International Conference on Public Communication of Science and Technology (PCST), Berlin, Germany, 17-19 September.

Kliment, T. (1994). Kernkraftprotest und Medienreaktionen. Deutungsmuster einer Widerstandsbewegung und öffentliche Rezeption. Wiesbaden: Deutscher Universitätsverlag. doi.org/10.1007/978-3-663-14607-0.

Koalitionsvertrag. (2013). Deutschlands Zukunft gestalten. Koalitionsvertrag zwischen CDU, CSU und SPD. 18. Legislaturperiode. Retrieved from www.cdu. de/sites/default/files/media/dokumente/koalitionsvertrag.pdf. 
Koch, K. and Stollorz, V. (2006). PR-Arbeiter und Journalist: Geht beides? In C. Götz-Sobel and W. Mock (eds), Wissenschaftsjournalismus heute. Ein Blick auf 20 Jahre WPK (pp. 103-10). Düsseldorf: VDI Verlag.

Koenen, E. and Meißner, M. (2019). Historische Perspektiven der Hochschulkommunikation. In B. Fähnrich, J. Metag, S. Post and M. S. Schäfer (eds), Forschungsfeld Hochschulkommunikation (pp. 39-59). Wiesbaden: Springer VS. doi.org/10.1007/978-3-658-22409-7_3.

Kohring, M. (2005). Wissenschaftsjournalismus: Forschungsüberblick und Theorieentwurf. Konstanz: UVK.

Krüger, J. (1985). Wissenschaftsberichterstattung in aktuellen Massenmedien aus der Sicht der Wissenschaftler. Ergebnisse einer Befragung der Professoren der Johannes Gutenberg-Universität. Unpublished magister thesis, Johannes Gutenberg-Universität Mainz.

Krüger, J. (1987). Wissenschaftsberichterstattung in aktuellen Massenmedien aus der Sicht der Wissenschaftler. In R. Flöhl and J. Fricke (eds), Moral und Verantwortung in der Wissenschaftsvermittlung: Die Aufgabe von Wissenschaftler und Journalist (pp. 39-51). Mainz: v. Hase \& Koehler.

Krüger, J. (1990). In der Aufbauphase. Berliner Modell I: Wissenschaftsjournalismus als Lehrangebot. In S. Ruß-Mohl (ed.), Wissenschaftsjournalismus und Öffentlichkeitsarbeit. Tagungsbericht zum 3 (pp. 133-36). Colloquium Wissenschaftsjournalismus vom 4./5. November 1988 in Berlin. Gerlingen: Bleicher Verlag.

Krüger, J. and Flöhl, R. (1982). Kein Platz auf dem Stundenplan. Wissenschaftsjournalismus in Forschung und Lehre. Deutsche Universitätszeitung, 38(6), 18-21.

Krüger, J. and Ruß-Mohl, S. (1989). Popularisierung der Technik durch Massenmedien. In L. Boehm and C. Schönbeck (eds), Technik und Kultur, Bd. 5: Technik und Bildung (pp. 385-415). Düsseldorf: VDI-Verlag. doi.org/ 10.1007/978-3-642-95790-1_6.

Laredo, P. (2007). Revisiting the third mission of universities: Toward a renewed categorisation of university activities? Higher Education Policy, 20(4), 441-56. doi.org/10.1057/palgrave.hep.8300169.

Lehmkuhl, M. (2012). The recent public understanding of science movement in Germany. In B. Schiele, M. Claessens and S. Shi (eds), Science Communication in the World (pp. 125-38). Dordrecht, NL: Springer. doi.org/10.1007/978-94007-4279-6_8. 
Lehmkuhl, M. (2019). Journalismus als Adressat von Hochschulkommunikation. In B. Fähnrich, J. Metag, S. Post and M. S. Schäfer (eds), Forschungsfeld Hochschulkommunikation (pp. 299-318). Wiesbaden: Springer VS. doi.org/ 10.1007/978-3-658-22409-7_14.

Leßmöllmann, A., Hauser, C. and Schwetje, T. (n.d. [2017]). Zwischenbericht. Hochschulkommunikation erforschen. Hochschulkommunikatoren als Akteure: Ergebnisse einer Online-Befragung - 1. Welle. Retrieved from www.geistsoz.kit. edu/germanistik/downloads/Zwischenbericht $\% 20$ Hochschulkommunikation $\% 20$ erforschen \%201.\%20Welle\%20Le\%C3\%9Fm\%C3\%B6llmann\%20Hauser\%20 Schwetje.pdf.

Lo, Y.-Y. (2016). Online communication beyond the scientific community. Scientists' use of new media in Germany, Taiwan and the United States to address the public (PhD thesis). Freie Universität Berlin, Germany. doi.org/10.17169/ refubium-11625.

Lohmar, U. (1972). Die Produktivkraft Wissenschaft als publisistisches Problem. Aus Politik und Zeitgeschichte, 22(B21), 3-15.

Marcinkowski, F. and Kohring, M. (2014). The changing rationale of science communication: a challenge to scientific autonomy. Journal of Science Communication, 13(3), C04. doi.org/10.22323/2.13030304.

Marcinkowski, F., Kohring, M., Fürst, S. and Friedrichsmeier, A. (2014). Organisational influence on scientists' efforts to go public: An empirical investigation. Science Communication, 36(1), 56-80. doi.org/10.1177/1075547013494022.

Mejlgaard, N., Bloch, C., Degn, L., Ravn, T. and Nielsen, M. W. (2012). Monitoring Policy and Research Activities on Science in Society in Europe (MASIS). Final synthesis report. Retrieved from rritrends.res-agora.eu/uploads/MASIS\%20 final\%20synthesis\%20report.pdf.

Metag, J. and Schäfer, M. S. (2019). Hochschulkommunikation in Online-Medien und Social Media. In B. Fähnrich, J. Metag, S. Post and M. S. Schäfer (eds), Forschungsfeld Hochschulkommunikation (pp. 363-92). Wiesbaden: Springer. doi.org/10.1007/978-3-658-22409-7_17.

Nagel, A. C. (2012). Hitlers Bildungsreformer. Das Reichsministerium für Wissenschaft, Erziehung und Volksbildung 1934-1945. Frankfurt: Fischer Verlag.

Newman, N., Fletcher, R., Kalogeropoulos, A., Levy, D. A. L. and Nielsen, R. K. (2017). Reuters Institute Digital News Report 2017. Retrieved from reutersinstitute. politics.ox.ac.uk/sites/default/files/Digital\%20News\%20Report $\% 202017 \% 20$ web_0.pdf. 
Noelle-Neumann, E. and Hansen, J. (1988). Medienwirkung und Technikakzeptanz: Kurzfassung des Allensbacher Berichts über ein Forschungsprojekt für das BMFT. In J. Scharioth and H. Uhl (eds), Medien und Technikakzeptanz (pp. 33-76). München: R. Oldenbourg Verlag. doi.org/10.1007/978-3-322-83727-1_22.

Noelle-Neumann, E. and Hansen, J. (1991). Technikakzeptanz in drei Jahrzehnten - in der Bevölkerung und in den Medien. Ein Beitrag zur Medienwirkungsforschung. In J. Krüger and S. Ruß-Mohl (eds), Risikokommunikation. Technikakzeptanz, Medien und Kommunikationsrisiken (pp. 91-143). Berlin: Edition Sigma.

Pansegrau, P., Taubert, N. and Weingart, P. (2011). Wissenschaftskommunikation in Deutschland: Ergebnisse einer Onlinebefragung. Unpublished report.

Peters, H. P. (1982). Vergleich physikalischer und soziologischer Wissenschaftsberichterstattung und Darstellung einiger Veränderungen auf den Wissenschaftsseiten von Zeitungen seit 1959. Soziologie, 11(1), 37-45.

Peters, H. P. (1994). Wissenschaftliche Experten in der öffentlichen Kommunikation über Technik, Umwelt und Risiken. Kölner Zeitschrift für Soziologie und Sozialpsychologie, 46(special issue 34), 162-90.

Peters, H. P. (2013). National Overview on Scientific Culture: GERMANY. Unpublished report prepared for the PLACES Project.

Peters, H. P. (2019). WissenschaftlerInnen als Kommunikatoren. In B. Fähnrich, J. Metag, S. Post, and M. S. Schäfer (eds), Forschungsfeld Hochschulkommunikation (pp. 209-25). Wiesbaden: Springer VS. doi.org/10.1007/978-3-658-22409-7_10.

Peters, H. P., Brossard, D., De Cheveigné, S., Dunwoody, S., Kallfass, M., Miller, S. and Paquez, A.-S. (2009). Kontakte biomedisinischer Forscher mit Journalisten und Öffentlichkeit: internationaler Vergleich von Erfahrungen und Einstellungen in Deutschland, Frankreich, Großbritannien, Japan und den USA. In H. P. Peters (ed.), Medienorientierung biomedisinischer Forscher im internationalen Vergleich. Die Schnittstelle von Wissenschaft \& Journalismus und ihre politische Relevanz (pp. 45-99). Jülich: Forschungszentrum Jülich.

Peters, H. P., Spangenberg, A. and Lo, Y.-Y. (2012). Variations of scientist-journalist interactions across academic fields: Results of a survey of 1600 German researchers from the humanities, social sciences and hard sciences. In M. Bucchi and B. Trench (eds), Quality, Honesty and Beauty in Science and Technology Communication: PCST 2012 Book of Papers (pp. 257-63). Vincenza: Observa Science in Society.

Pew Research Center. (2016). Smartphone Ownership and Internet Usage Continues to Climb in Emerging Economies. Retrieved from www.pewresearch.org/global/ wp-content/uploads/sites/2/2016/02/pew_research_center_global_technology_ report_final_february_22_2016.pdf. 
Projektgruppe ARD/ZDF-Multimedia. (2017). Kernergebnisse der ARD/ZDFOnlinestudie 2017. Retrieved from www.ard-zdf-onlinestudie.de/files/2017/ Artikel/Kern-Ergebnisse_ARDZDF-Onlinestudie_2017.pdf.

Pütz, J. (2006). Die WPK profiliert sich. Gründungsgeschichte. In C. Götz-Sobel and W. Mock (eds), Wissenschaftsjournalismus heute. Ein Blick auf 20 Jahre WPK (pp. 117-21). Düsseldorf: VDI Verlag.

Renn, O., Stegelmann, H. U., Albrecht, G., Kotte, U. and Peters, H. P. (1984). An empirical investigation of citizens' preferences among four energy scenarios. Technological Forecasting and Social Change, 26(1), 11-46. doi.org/10.1016/00401625(84)90042-8.

Robert Bosch Stiftung. (ed.) (1983). Wissenschaftsjournalismus und Journalistenausbildung. Eine Bestandsaufnahme. Tagungsbericht zum 1. Colloquium Wissenschaftsjournalismus vom 10./11. Dezember 1982 in Stuttgart-Hohenheim. Stuttgart: Robert Bosch Stiftung.

Robert Bosch Stiftung. (ed.) (1985). Wissenschaftsjournalismus in den USA: Infrastrukturen, Ausbildungsangebote, Erfolgsgeheimnisse. Tagungsbericht zum 2. Colloquium Wissenschaftsjournalismus vom 10./11. Februar 1984 in StuttgartDegerloch. Stuttgart: Robert Bosch Stiftung.

Roloff, E. K. and Hömberg, W. (1975). Wissenschaftsjournalisten. Dolmetscher zwischen Forschung und Öffentlichkeit. Bild der Wissenschaft, 12(9), 56-60.

Ruhrmann, G., Kessler, S. H. andGuenther,L.(eds) (2017). Wissenschaftskommunikation zwischen Risiko und (Un-)Sicherheit. Köln: von Halem.

Ruß-Mohl, S. (1985). Wissenschaftsjournalismus im gelobten Land-Anmerkungen und Fragen aus der Diaspora. In Robert Bosch Stiftung (ed.), Wissenschaftsjournalismus in den USA. Infrastrukturen, Ausbildungsangebote, Erfolgsgeheimnisse. Tagungsbericht zum 2. Colloquium Wissenschaftsjournalismus vom 10./11. Februar 1984 in Stuttgart-Degerloch. Stuttgart: Robert Bosch Stiftung.

Sager, D. (1975). Journalistenausbildung in der DDR. In J. Aufermann and E. Elitz (eds), Ausbildungswege zum Journalismus. Bestandsaufnahmen, Kritik und Alternativen der Journalistenausbildung (pp. 108-16). Wiesbaden: VS Verlag für Sozialwissenschaften. doi.org/10.1007/978-3-322-85398-1_7.

Schäfer, M. S., Kristiansen, S. and Bonfadelli, H. (eds) (2015). Wissenschaftskommunikation im Wandel. Köln: von Halem.

Schemmert, C. and Siemens, D. (2013). Die Leipziger Journalistenausbildung in der Ära Ulbricht. Vierteljahrshefte für Zeitgeschichte, 61(2), 201-37. doi.org/10.1524/ vfzg.2013.0010. 
Schmidt, H. (1977). Verantwortung der Forschung für die Zukunft der Gesellschaft. Ansprache des Bundeskanzlers vor der Deutschen Forschungsgemeinschaft. In Bulletin. Presse-und Informationsamt der Bundesregierung, no. 72/1977, pp. 673-79.

Schmidt, H. (2005). Das vornehme Schweigen: Die Niederungen der Politik und die Wissenschaft. In WZB Mitteilungen, no. 107, pp. 11-12.

Schmidt-Lux, T. (2008). Das helle Licht der Wissenschaft. Geschichte und Gesellschaft, 34(1), 41-72. doi.org/10.13109/gege.2008.34.1.41.

Schnabel, U. (2008). Zeit für einen neuen Push. Gegenworte, 19, 16-20.

Schneider, A. (2012). Events als Kommunikationsinstrument im Hochschulmarketing. In C. Zanger (ed.), Erfolg mit nachhaltigen Eventkonzepte (pp. 35-58). Wiesbaden: Springer. doi.org/10.1007/978-3-8349-6885-2_4.

Serong, J., Koppers, L., Luschmann, E., Molina Ramirez, A., Kersting, K., Rahnenführer, J. and Wormer, H. (2017). Öffentlichkeitsorientierung von Wissenschaftsinstitutionen und Wissenschaftsdisziplinen - Eine Längsschnittsanalyse des 'Informationsdienstes Wissenschaft' (idw) 1995-2015. Publizistik, 62(2), 153-78. doi.org/10.1007/s11616-017-0336-6.

Spinner, H. F. (1985). Das 'wissenschaftliche Ethos' als Sonderethik des Wissens: über das Zusammenwirken von Wissenschaft und Journalismus im gesellschaftlichen Problemlösungsprozes. Tübingen: Mohr.

Stifterverband. (1999). Dialog Wissenschaft und Gesellschaft. Symposium 'Public Understanding of the Sciences and Humanities - International and German Perspectives', 27 Mai, Wissenschaftszentrum Bonn. Stifterverband, Essen.

Stollorz, V. and Meurer, M. (2015). Deutsches Science Media Center kommt. Meta. Das Magazin über Journalismus und Wissenschaft. Retrieved from www.metamagazin.org/2015/06/04/faq-deutsches-science-media-center-kommt-2016/.

Strömer, A. (1999). Wissenschaft und Journalismus 1984-1997: Ergebnisse einer Befragung von Berliner Professoren sowie wissenschaftlichen Mitarbeitern des Forschungszentrums Jülich und Vergleiche mit einer früheren Studie aus Mainz und Jülich. Unpublished magister thesis, Freie Universität Berlin, Germany.

Tonnemacher, J. (1982). Fallbeispiel XIII: Öffentlichkeitsarbeit an Hochschulen - Ein Fallbeispiel über die Vermittlung von Hochschulpolitik und Universitätsforschung an die Öffentlichkeit. In G. Haedrich, G. Barthenheier and H. Kleinert (eds), Öffentlichkeitsarbeit. Dialog zwischen Institutionen und Gesellschaft. Ein Handbuch (pp. 367-80). Berlin: Walter de Gruyter.

UK House of Lords Select Committee on Science and Technology. (2000). Science and Society: 3rd Report of the Session 1999-2000. London: HM Stationery Office. 
Weber, W. (1993). The political history of museums of technology in Germany since the nineteenth century. History and Technology, 10(1), 13-25. doi.org/ $10.1080 / 07341519308581832$.

Weingart, P. (2001). Die Stunde der Wahrheit? Zum Verhältnis der Wissenschaft zu Politik, Wirtschaft und Medien in der Wissensgesellschaft. Weilerswist: Velbrück Wissenschaft.

Weingart, P. (2012). The lure of the mass media and its repercussions on science. In S. Rödder, M. Franzen and P. Weingart (eds), The Sciences' Media Connection - Public Communication and its Repercussions (pp. 17-32). Dordrecht, NL: Springer. doi.org/10.1007/978-94-007-2085-5_2.

Weingart, P., Pansegrau, P., Rödder, S. and Voß, M. (2007). Vergleichende Analyse Wissenschaftskommunikation: Abschlussbericht für das BMBF. Universität Bielefeld, Institut für Wissenschafts-und Technikforschung (IWT), Bielefeld.

Weingart, P., Wormer, H., Wenninger, A. and Hüttl, R. F. (eds) (2017). Perspektiven der Wissenschaftskommunikation im digitalen Zeitalter. Weilerswist: Velbrück Wissenschaft.

Weitze, M.-D. and Heckl, W. M. (2016). Wissenschaftskommunikation-Schlüsselideen, Akteure, Fallbeispiele. Berlin: Springer Spektrum. doi.org/10.1007/978-3-66247843-1.

Weßler, H. (1995). Die journalistische Verwendung sozialwissenschaftlichen Wissens und ihre Bedeutung für gesellschaftliche Diskurse. Publizistik, 40(1), 20-38.

Wilke, T. (2013). Die Urania Gesellschaft und die Popularisierung naturwissenschaftlicher Erkenntnisse am Ende des 19. Jahrhunderts. Medien \& Zeit, 28(4), 5-13.

Wissenschaft im Dialog. (2017). Debatten anstoßen, Erkenntnisprozesse kommunisieren und neue Zielgruppen ansprechen. Strategiepapier $2017 \mathrm{der}$ Wissenschaft im Dialog gGmbH. Retrieved from www.wissenschaft-im-dialog.de/fileadmin/user_ upload/Ueber_uns/WiD_dokumente/Strategiepapier_WiD_2017.pdf.

Wissenschaft im Dialog. (2018). Tabellenband Wissenschaftsbarometer 2018. Retrieved from www.wissenschaft-im-dialog.de/fileadmin/user_upload/Projekte/Wissen schaftsbarometer/Dokumente_18/Downloads_allgemein/Tabellenband_Wissen schaftsbarometer2018_final.pdf.

Wissenschaftszentrum Berlin. (1976). Die Vermittlung von sozialwissenschaftichen Ergebnissen an die Öffentlichkeit. Konferenz Wissenschaftszentrum Berlin (WZB) 5./6. Dezember 1975. WZB-paper GS 1976-1. Wissenschaftszentrum Berlin für Sozialforschung, Berlin.

Wormer, H. (ed.) (2006). Die Wissensmacher: Profile und Arbeitsfelder von Wissenschaftsredaktionen in Deutschland. Wiesbaden: VS Verlag für Sozialwissenschaften. 


\section{Timeline}

\begin{tabular}{|c|c|c|c|}
\hline Event & Name & Date & Comment \\
\hline $\begin{array}{l}\text { First interactive } \\
\text { science centre } \\
\text { established. }\end{array}$ & $\begin{array}{l}\text { Phänomenta } \\
\text { Flensburg opened } \\
\text { (Kiupel 1993) }\end{array}$ & 1993 & $\begin{array}{l}\text { Phänomenta was based on } \\
\text { hands-on exhibits presented in the } \\
\text { University of Flensburg since } 1985 \\
\text { 2000: Opening of the larger science } \\
\text { centre Universum Bremen }\end{array}$ \\
\hline $\begin{array}{l}\text { First national (or } \\
\text { large regional) } \\
\text { science festival. }\end{array}$ & $\begin{array}{l}\text { Launch of 'science } \\
\text { summers' organised } \\
\text { by Wissenschaft in } \\
\text { Dialog }\end{array}$ & $\begin{array}{l}2000- \\
2012\end{array}$ & $\begin{array}{l}\text { Funded by the Federal Ministry } \\
\text { of Education and Research }\end{array}$ \\
\hline $\begin{array}{l}\text { An association } \\
\text { of science } \\
\text { writers or } \\
\text { journalists or } \\
\text { communicators } \\
\text { established. }\end{array}$ & $\begin{array}{l}\text { Foundation of } \\
\text { Technisch Literarische } \\
\text { Gesellschaft (TELI), } \\
\text { an association of a } \\
\text { diverse spectrum of } \\
\text { people interested in } \\
\text { science popularisation } \\
\text { (based on precursor } \\
\text { associations) }\end{array}$ & 1929 & $\begin{array}{l}\text { 1969: Foundation of the } \\
\text { Association of University Press } \\
\text { Officers (Bundesverband } \\
\text { Hochschulkommunikation) } \\
\text { 1986: German Association of } \\
\text { Science Journalists (WPK) } \\
\text { 2012: Science Communication } \\
\text { Section of the German } \\
\text { Communication Association (DGPuK) }\end{array}$ \\
\hline $\begin{array}{l}\text { First university } \\
\text { courses to } \\
\text { train science } \\
\text { communicators. }\end{array}$ & $\begin{array}{l}\text { Beginning of sporadic } \\
\text { science journalism } \\
\text { courses in general } \\
\text { communication } \\
\text { programs (U Mainz) }\end{array}$ & 1980 & $\begin{array}{l}\text { 1988: Launch of a regular } \\
\text { postgraduate program } \\
\text { (Aufbaustudiengang) in science } \\
\text { journalism (FU Berlin), aimed at } \\
\text { science graduates wanting to } \\
\text { become science journalists }\end{array}$ \\
\hline $\begin{array}{l}\text { First master's } \\
\text { students } \\
\text { in science } \\
\text { communication } \\
\text { graduate. }\end{array}$ & $\begin{array}{l}\text { Technical University } \\
\text { of Dortmund }\end{array}$ & 2009 & $\begin{array}{l}\text { Master's program on science } \\
\text { journalism launched in the winter } \\
\text { term 2007/08 }\end{array}$ \\
\hline $\begin{array}{l}\text { First PhD } \\
\text { students } \\
\text { in science } \\
\text { communication } \\
\text { graduate. }\end{array}$ & $\begin{array}{l}\text { The first PhD theses } \\
\text { on science in the } \\
\text { media date back to } \\
\text { the early } 1970 \text { s }\end{array}$ & $\begin{array}{l}\text { Early } \\
\text { 1970s }\end{array}$ & $\begin{array}{l}\text { First postgraduate research program: } \\
\text { DFG-Graduiertenkolleg, Bielefeld } \\
2002-11 \text {. Most Germany doctoral } \\
\text { dissertations are outside formal } \\
\text { postgraduate programs by individual } \\
\text { agreements between a PhD student } \\
\text { and a supervising professor }\end{array}$ \\
\hline $\begin{array}{l}\text { First national } \\
\text { conference } \\
\text { in science } \\
\text { communication. }\end{array}$ & $\begin{array}{l}\text { Many workshops } \\
\text { on science and } \\
\text { the media with } \\
\text { scientists, science } \\
\text { journalists, public } \\
\text { information officers } \\
\text { and communication } \\
\text { scholars }\end{array}$ & $\begin{array}{l}1960 s \\
\text { to } \\
1970 s\end{array}$ & $\begin{array}{l}\text { 2004: Launch of the annual } \\
\text { conference series Wissenswerte, for } \\
\text { science journalists } \\
\text { 2008: Launch of general science } \\
\text { communication conference Forum } \\
\text { Wissenschaftskommunikation } \\
\text { 2012: Launch of annual } \\
\text { conferences of the Science } \\
\text { Communication Section of } \\
\text { the German Communication } \\
\text { Association (DGPuK) }\end{array}$ \\
\hline
\end{tabular}




\begin{tabular}{|c|c|c|c|}
\hline Event & Name & Date & Comment \\
\hline $\begin{array}{l}\text { National } \\
\text { government } \\
\text { program to } \\
\text { support science } \\
\text { communication } \\
\text { established. }\end{array}$ & $\begin{array}{l}\text { Memorandum Public } \\
\text { Understanding } \\
\text { of Science and } \\
\text { Humanities (PUSH). } \\
\text { Not a government } \\
\text { report but a } \\
\text { functional equivalent, } \\
\text { issued by the major } \\
\text { German research } \\
\text { organisations in } \\
\text { collaboration with } \\
\text { Stifterverband }\end{array}$ & 1999 & $\begin{array}{l}\text { 2016: Position paper on participation } \\
\text { of civil society and public in science } \\
\text { and science policy by the Federal } \\
\text { Ministry of Education and Research }\end{array}$ \\
\hline $\begin{array}{l}\text { First significant } \\
\text { initiative or } \\
\text { report on } \\
\text { science } \\
\text { communication. }\end{array}$ & $\begin{array}{l}\text { Memorandum Public } \\
\text { Understanding } \\
\text { of Science and } \\
\text { Humanities (PUSH) }\end{array}$ & 1999 & $\begin{array}{l}\text { 2016: Position paper on participation } \\
\text { of civil society and public in science } \\
\text { and science policy by the Federal } \\
\text { Ministry of Education and Research }\end{array}$ \\
\hline $\begin{array}{l}\text { National } \\
\text { Science Week } \\
\text { founded. }\end{array}$ & $\begin{array}{l}\text { Launch of the series } \\
\text { of Wissenschaftsjahre } \\
\text { [Science Years] }\end{array}$ & 2003 & $\begin{array}{l}\text { Science Years (where each year is } \\
\text { devoted to a particular discipline } \\
\text { or topic, e.g. chemistry (2003), } \\
\text { humanities (2007) etc.) are the } \\
\text { German equivalent of national } \\
\text { science weeks }\end{array}$ \\
\hline $\begin{array}{l}\text { First significant } \\
\text { TV programs } \\
\text { on science. }\end{array}$ & $\begin{array}{l}\text { Launch of the popular } \\
\text { TV series Ein Platz für } \\
\text { wilde Tiere [A place } \\
\text { for wild animals] with } \\
\text { Professor Bernhard } \\
\text { Grzimek. It focused } \\
\text { on nature, yet } \\
\text { scientific expertise } \\
\text { was used to describe } \\
\text { and explain animals }\end{array}$ & 1956 & $\begin{array}{l}\text { 1960s: Documentaries about the } \\
\text { US spaceflight program (journalists: } \\
\text { Heinrich Schiemann, ZDF, and } \\
\text { Günther Siefarth, WDR) } \\
\text { 1964: Launch of the } \\
\text { popular TV health magazine } \\
\text { Gesundheitsmagazin Praxis (ZDF) } \\
\text { with Hans Mohl } \\
\text { 1964: Creation of editorial offices } \\
\text { for science in TV channels ARD } \\
\text { and ZDF; two regular TV science } \\
\text { programs were launched }\end{array}$ \\
\hline $\begin{array}{l}\text { Date hosted } \\
\text { a PCST } \\
\text { conference. }\end{array}$ & $\begin{array}{l}\text { 5th International } \\
\text { PCST Conference, } \\
\text { Berlin }\end{array}$ & 1998 & \\
\hline $\begin{array}{l}\text { Other significant } \\
\text { events. }\end{array}$ & & & $\begin{array}{l}\text { 1830: Journalists specialising in the } \\
\text { reporting of science and technology } \\
\text { at the newspaper Kölnische Zeitung } \\
\text { (Krüger and Ruß-Mohl, 1989) } \\
\text { 1903: Launch of the popular science } \\
\text { magazine Kosmos }\end{array}$ \\
\hline
\end{tabular}




\section{Contributors}

Dr Hans Peter Peters is a social scientist at the Research Center Juelich, Germany, and adjunct professor of Science Journalism at the Free University of Berlin. He has been a member of the PCST Scientific Committee since 2002, and is editor of Public Understanding of Science and editor of the book series Science Communication, of World Scientific Publishing (WSPC).

Dr Markus Lehmkuhl is a full professor of Science Communication in Digital Media at Karlsruhe Institute of Technology (KIT). Since 2000 he has done research on the public perception of risk, media coverage of science in Germany and Europe, and on the journalistic construction of scientific uncertainty.

Dr Birte Fähnrich is senior researcher at the Berlin-Brandenburg Academy of Sciences and Humanities and principle investigator in the EU-funded project RETHINK for Zeppelin University. She is a member of the PCST committee. 
This text is taken from Communicating Science: A Global Perspective, edited by Toss Gascoigne, Bernard Schiele, Joan Leach, Michelle Riedlinger, Bruce V. Lewenstein, Luisa Massarani and Peter Broks, published 2020 by ANU Press, The Australian National University, Canberra, Australia.

doi.org/10.22459/CS.2020.14 